\title{
Rancang Bangun Sistem Proteksi Generator Sinkron 3 Phasa Terhadap Arus Beban lebih dan Drop Tegangan Berbasis Mikrokontroler Arduino
}

Oleh:

Rifdian I.S

Hartono

\author{
Politeknik Penerbangan Surabaya \\ Jl. Jemur Andayani I, No. 73 Surabaya 60236 \\ Email : rifdian.anto@gmail.com
}

\begin{abstract}
ABSTRAK
Abstrak-Proteksi pada generator sinkron 3 phasa meliputi proteksi arus, tegangan, frekuensi dan putaran. Pada penelitian ini difokuskan pada rancangan proteksi arus beban lebih dan proteksi drop tegangan pada generator. Sistem proteksi ini merupakan sistem proteksi generator yang menggunakan arduino sebagai pengolah data yang dibaca oleh sensor arus dan tegangan. Apabila pembacaan pada sensor arus dan tegangan melebihi dari batasan yang disetting, maka secara otomatis suplai daya dari sumber terputus. Sehingga dapat melindungi motor dan generator dari kerusakan. Pemutusan suplai daya tersebut menggunakan kontaktor yang terhubung dengan relay. Relay ini dikontrol oleh arduino. Untuk penyetingan arus digunakan rumus dengan melalui perhitungan didapat setpoint untuk arus sebesar 1,43 Ampere. Nilai arus ini adalah $110 \%$ dari arus nominal generator. Setting tegangan per phasa diperoleh melalui perhitungan, sehingga didapat tegangan drop yang diperbolehkan adalah sebesar 198 volt. Tegangan drop ini adalah sebesar 10\% dari tegangan nominalnya yaitu sebesar 220 volt.
\end{abstract}

Kata Kunci : sistem proteksi, generator sinkron, arus beban lebih, drop tegangan, mikrontroler

\section{PENDAHULUAN}

Penggunaan generator didalam suatu sistem kelistrikan pembangkit sangat dibutuhkan dimana kegunaan dari generator ini sendiri adalah sebagai pengubah energi mekanik atau energi gerak menjadi energi listrik. Generator ini terhubung ke motor sebagai penggeraknya. Motor dan generator ini memiliki batasan kemampuan yang dapat ditopang oleh masing masingnya. Contohnya saja kejadian yang sering terjadi adalah gangguan terhadap arus beban lebih dan drop tegangan. Hal ini kebanyakkan terjadi karena pemakaian beban yang berlebihan. Oleh sebab itu dibutuhkannya sistem proteksi terhadap arus beban lebih dan drop tegangan untuk motor dan generator ini. Dari hal tersebut penulis bertujuan untuk membuat penelitian "Rancang Bangun Sistem Proteksi Generator Sinkrn 3 phasa Terhadap Arus Beban Lebih dan Drop Tegangan Berbasis Mikrokontroller Arduino" dimana sistem ini akan dikontrol secara otomatis oleh arduino, bukan sistem proteksi yang dilakukan secara konvensional. Dalam aplikasinya, pada generator tersebut arus dan tegangan masing-masing fasa akan di setting sesuai perhitungan arus lebih dan batasan drop tegangan dari generator tersebut.

\section{Sistem Proteksi}

Sistem proteksi adalah susunan peralatan yang direncanakan untuk dapat merasakan, mengukur adanya gangguan dan menentukan letak gangguan atau mulai mendeteksi adanya ketidaknormalan pada peralatan atau sebagian sistem tenaga listrik dan segera secara 
otomatis membuka pemutusan beban untuk memisahkan peralatan atau bagian dari sistem yang terganggu dan memberi isyarat berupa lampu, alarm dan lain sebagainya.

\section{Proteksi Arus Beban Lebih}

Arus beban lebih merupakan kenaikan arus yang terjadi dikarenakan adanya beban yang berlebihan (overload) pada sistem. Proteksi arus beban lebih ini akan bekerja apabila dan memutus ketika arus pada rangkaian melebihi arus setting (Iset) yang telah diatur. Menurut PUIL 2000 bagian 5.5.4.1 ; proteksi beban lebih (arus lebih) dimaksudkan untuk melindungi motor dan perlengkapan kendali motor, terhadap pemanasan berlebihan sebagai akibat beban lebih. Beban lebih atau arus lebih pada waktu mesin listrik berjalan bila bertahan cukup lama akan mengakibatkan kerusakan atau pemanasan yang berbahaya pada mesin listrik tersebut. Proteksi arus beban lebih ini bekerja berdasarkan besarnya arus masukan. Jika arus beban melebihi suatu harga tertentu yang dapat diatur (Iset), maka relai ini akan bekerja.

Ibeban > Isetting, maka relai bekerja (trip)

Ibeban < Isetting, maka relai tidak bekerja

Untuk penyetingan arus beban lebih pada sistem ini dapat diatur dengan menggunakan rumus sebagaimana berikut :

1. Arus maksimal (Imax) beban :

$\mathrm{P}=\mathrm{V} . \mathrm{I}$

$\mathrm{P}=\mathrm{V} . \mathrm{I} \cdot \cos \Theta$

Atau bisa juga menggunakan rumus berikut

$\mathrm{V}=\mathrm{I} . \mathrm{R}$

2. Menentukan Isetting :

Isetting $=110 \% . \mathrm{I}$

Setelah dilakukan perhitungan dengan menggunakan teori diatas, maka baru dilakukan pengujian lansung pada alat. Kemudian akan dibandingkan dengan hasil dari pengukuran.

\section{Proteksi Drop Tegangan}

Untuk meningkatkan kualitas daya listrik, perlu dilakukan pengurangan berbagai permasalahan yang menyebabkan buruknya kualitas daya listrik. Salah satu permasalahan tersebut adalah undervoltage atau tegangan turun. Maka biasanya digunakan rele yang bekerja dengan menggunakan tegangan sebagai besaran ukur. Rele akan bekerja jika mendeteksi adanya penurunan tegangan melampaui batas yang telah ditetapkan. Beberapa peralatan yang beroperasi dengan tegangan di bawah $10 \%$ akan mengalami penurunan efisiensi. Tegangan turun termasuk ke dalam long duration variation, dimana waktu kejadiannya adalah lama. Penyebab terjadinya tegangan jatuh adalah karena pengkawatan pada sistem yang kurang baik dan pembebanan yang berlebih pada sistem (overload). Akibat dari terjadinya gangguan ini adalah degradasi pada peralatan elektronik (berkurangnya masa penggunaan alat), dapat merusak belitan rotor, dan motor cepat panas. Maka dari itu dibutuhkan proteksi dari gangguan ini.

Untuk menentukan besar drop tegangan ini biasanya dilakukan dalam perhitungan persen (\%). Penetapan itu melakukan pengukuran besar kecilnya drop tegangan yang terjadi, maka dapat dicari dengan menggunakan rumus berikut :

$$
\begin{aligned}
& \text { Vsetting }=\mathrm{V} . \mathrm{n} \% . \\
& \text { Vsetting }=\mathrm{V}-\mathrm{n} \% .
\end{aligned}
$$

Keterangan :

n $\%=$ besar tegangan turun (dalam persen)

$\mathrm{V}=$ tegangan 


\section{METODE PENELITIAN}

Rancangan alat dari penelitian ini menggunakan 2 sensor, yaitu menggunakan sensor ACS712 dan sensor ZMPT101b. Kedua sensor tersebut digunakan untuk melakukan pendeteksian arus dan tegangan. Untuk melakukan proteksi terhadap arus beban lebih, pada alat ini akan digunakan sensor ACS712 sebagai pendeteksi arus. Pemasangan sensor arus dilakukan secara seri dalam rangkaian. Apabila sensor arus membaca arus yang melewatinya melebihi dari Isetting-nya, maka arduino sebagai pengontrol dalam rangkaian tersebut akan memberikan intruksi kepada relay untuk mematikan suplai tenaga dari generator ke beban melalui Circuit Breaker/PMT. Kemudian untuk melakukan proteksi terhadap drop tegangan. Pada alat ini akan digunakan sensor ZMPT101b sebagai pendeteksi tegangan. Pemasangan sensor tegangan ini dilakukan secara paralel pada rangkaian. Apabila sensor tegangan membaca tegangan yang melewatinya dibawah Vsetting-nya, maka arduino akan memberikan instruksi kepada relay untuk melakukan pemutusan suplai tenaga dari generator ke beban.

Untuk lebih lengkapnya mengenai perancangan sistem proteksi generator dari arus beban lebih dan drop tegangan berbasiskan mikrokontroller arduino ini, maka akan jelas terlihat pada blok diagram berikut :

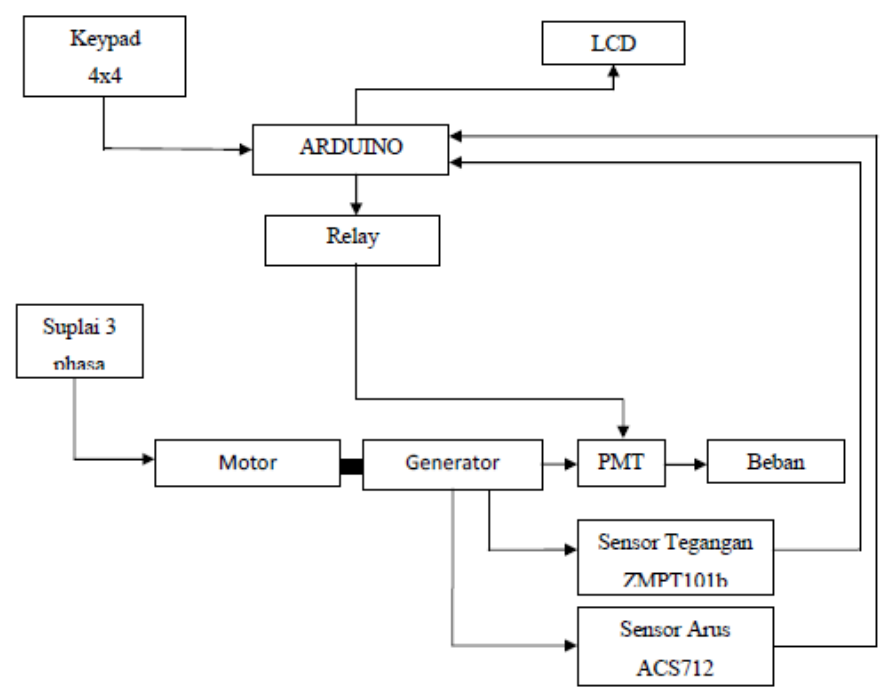

Gambar 1. Blok diagram rancangan

Fungsi masing-masing komponen yang terdapat pada blok diagram diatas adalah sebagai berikut :

1. Arduino, digunakan sebagai mikrokontroler untuk memproses data yang masuk dari sensor dan keypad serta untuk mengontrol sistem alat tersebut, sehingga bisa didapatkan output sesuai dengan yang diinginkan.

2. LCD (Liquid Cristal Display)

Display elektronika adalah salah satu komponen elektronika yang berfungsi sebagai tampilan suatu data, baik karaktek, huruf ataupun grafik. LCD adalah salah satu jenis display elektronik yang dibuat dengan teknologi CMOS logic yang bekerja dengan tidak menghasilkan cahaya tetapi memantulkan cahaya yang ada di sekelilingnya.

3. Keypad 4x4

Keypad 4x4 berfungsi untuk mensetting atau mengatur nominal nilai arus dan tegangan serta untuk mengatur waktu tunda pemutusan PMT. Keypad matrik $4 \times 4$ berfungsi sebagai interface antara perangkat elektronik yang digunakan sebagai input, yang mana nantinya akan mengirimkan data ke arduino mega 2560 untuk di proses.

4. PMT, terdiri dari relay dan kontaktor yang berfungsi sebagai swicth otomatis untuk memutuskan rangkaian apabila ada terjadi gangguan pada sistem proteksi tersebut. Relay 
akan menerima perintah untuk memutus dari arduino apabila telah terjadi gangguan pada sistem, sehingga kontaktor nantinya akan memutus suplai tenaga ke beban.

5. Sensor ACS712, merupakan sensor yang digunakan untuk melakukan pengukuran arus pada sistem. Kapasitas maksimal pembacaan sensor arus yang digunakan adalah sebesar 30 A. Namun untuk keamanan, arus yang boleh diukur nantinya akan dibatasi sebesar 5 A.

6. Sensor ZMPT101B, merupakan sensor yang digunakan untuk melakukan pengukuran tegangan. Data pengukuran yang didapat dari sensor ini nantinya akan diolah oleh mikrokontroler apakah telah melewati setting atau belum. Sensor ini nantinya akan dipasang secara paralel pada rangkaian. Karena pemasangan sensor ini tidak dapat dilakukan secara line to line (380 volt) maka untuk pemasangan sensor ini dilakukan dengan cara line to netral (220 volt).

7. Generator Sinkron, merupakan pembangkit energi listrik yang akan diproteksi. Generator merupakan suatu mesin listrik yang dapat mengubah energi gerak atau mekanik menjadi energi listrik dengan menggunakan prinsip GGL induksi untuk membangkitkan listrik. Berikut merupakan data dari generator yang digunakan :

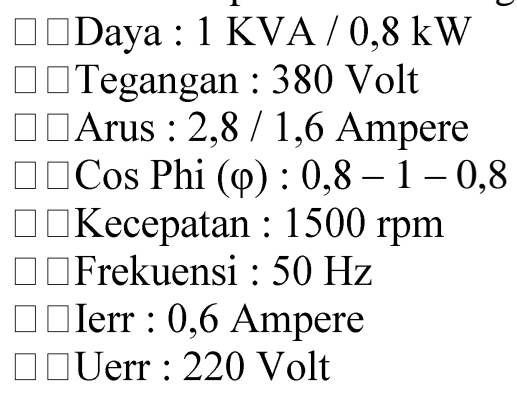

Algoritma dari rancang bangun alat sistem proteksi arus beban lebih dan drop tegangan pada generator adalah sebagai berikut :

1. Melakukan penyetingan Isetting dan Vsetting serta waktu tunda (tsetting) untuk pemutusan pada PMT dengan menggunakan keypad 4x4.

2. Sensor arus ACS712 mendeteksi arus pada keluaran generator.

3. Sensor tegangan ZMPT101B mendeteksi besar keluaran dari generator.

4. Lampu indikator akan mati apabila terjadi arus beban lebih atau drop tegangan pada sistem.

5. Modul relay NO (Normally Open) apabila terjadi arus beban lebih atau drop tegangan.

6. Untuk pengulangan direset terlebih dahulu.

Algoritma di atas disusun dalam sebuah flowchart sesuai gambar 2. Prinsip kerja dari alat ini adalah apabila sensor arus dan tegangan membaca arus dan tegangan yang melewati dari nilai set point yang sudah ditetapkan, maka sistem yang dikontrol oleh arduino akan mentripkan suplai listrik ke beban. Ini berlaku jika nilai pengukuran arus beban sudah melewati nilai set point dari arus yang di inputkan. Untuk tegangannya apabila pengukuran sensor tegangan sudah berada dibawat nilai set point yang diinputkan, maka PMT yang dihubungkan ke relay dan dikontrol oleh arduino akan trip, sehingga suplai ke beban terputus. Kemudian apabila arus dan tegangan sudah melewati nilai set point yang ditentukan, selain ouputnya adalah ke PMT, maka buzzer juga akan menyala menandakan adanya masalah pada sistem dan segera untuk diperiksa. Semua pengukuran arus dan tegangan, nilai set point yang diinputkan akan ditampilkan di LCD. Skema keseluruhan alat ditunjukkan pada gambar 3.

\section{PENGUJIAN ALAT DAN PEMBAHASAN}

Pada rancangan ini, maksimal pembacaaan arus dengan menggunakan sensor ini adalah sebesar $30 \mathrm{~A}$. Sebelum sensor arus ini digunakan dalam sistem, terlebih dahulu dilakukan pengujian sensor dengan membandingkan nilai pembacaan sensor dengan ampermeter. 
Untuk pengujian sensor arus ini digunakan lampu pijar sebagai beban. Beban lampu pijar ini pun divariabelkan, sehingga uttuk setiap pengujian tidak mengunakan besar beban yang sama. Untuk tegangan yang digunakan sebesar 220 Volt dan 188 Volt. Hal ini dilakukan agar diketahui sensitifitas dari sensor tersebut. Kemudian pembacaan sensor tersebut akan dibandingkan dengan pengukuran yang dilakukan dengan ampermeter.

Tabel 1,2 dan 3 merupakan hasil pengujian sensor arus ACS712 tersebut.

Grafik perbandingan pengukuran antara sensor arus ACS712 dengan ampermeter ditunjukkan pada tabel 1-3. Pada pengukuran pengukuran tersebut beban yang digunakan divariasikan. Beban yang dipakai adalah lampu pijar 25 watt, 40 watt, 65 watt, 140 watt.

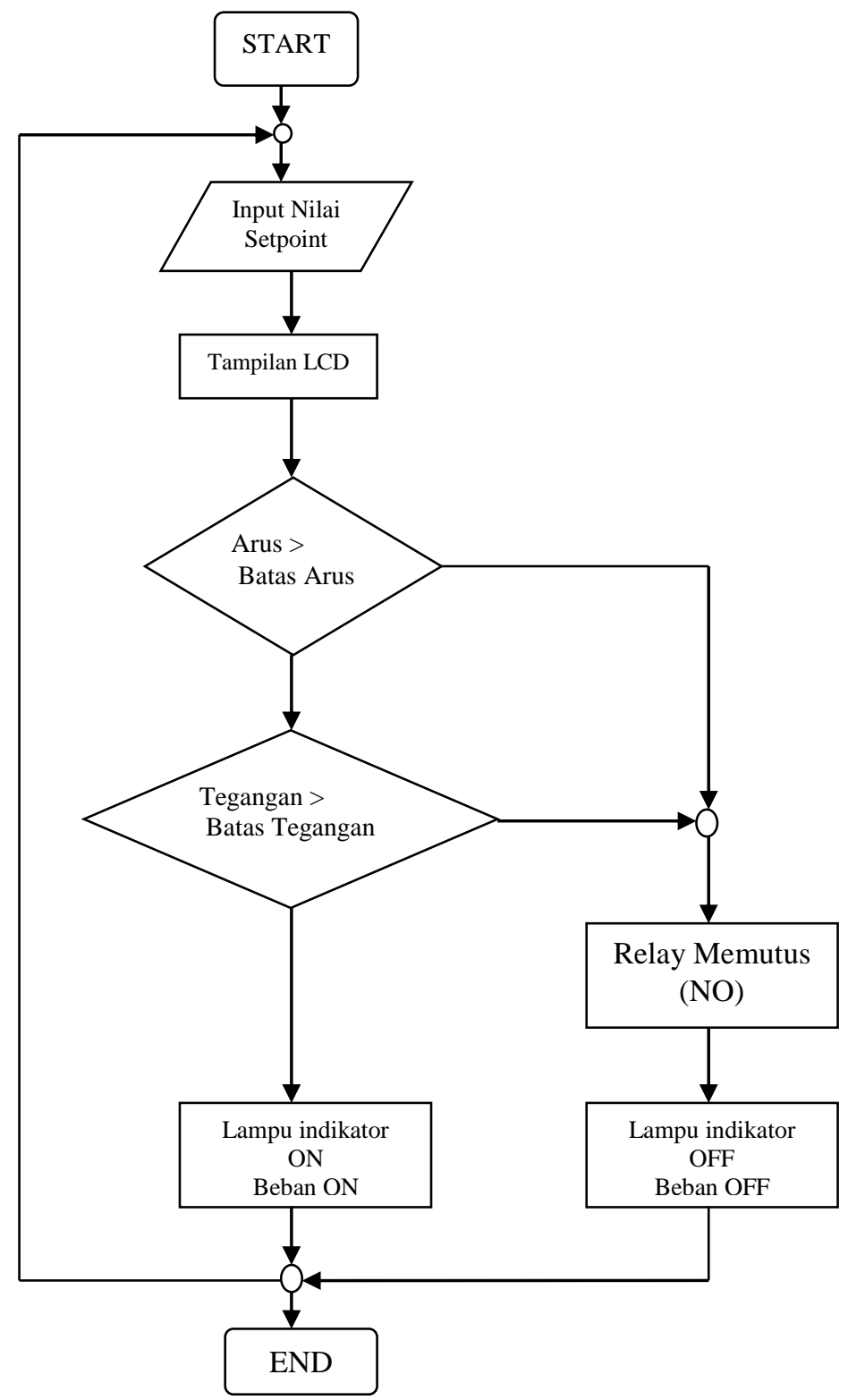

Gambar 2. Flowchart rangkaian 


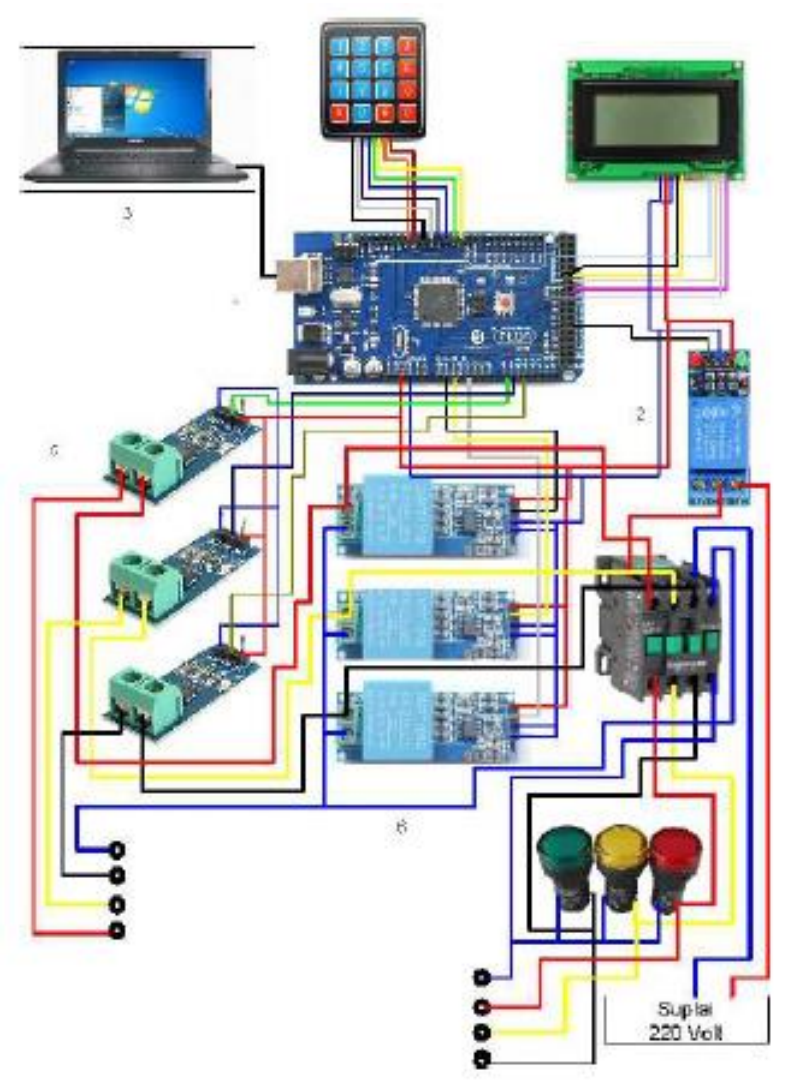

Gambar 3. Skema rancangan secara keseluruhan

Tabel 1. Pengujiam sensor ACS712 dengan tegangan 220Vac

\begin{tabular}{|c|c|c|c|c|c|c|c|}
\hline \multirow{2}{*}{$\begin{array}{c}\text { Tegangan } \\
(\mathrm{Vs})\end{array}$} & \multirow{2}{*}{$\begin{array}{c}\text { Beban } \\
\text { (Watt) }\end{array}$} & \multicolumn{3}{|c|}{ Sensor } & \multicolumn{3}{|c|}{ Ampermeter } \\
\cline { 3 - 8 } & & $\mathrm{R}(\mathrm{A})$ & $\mathrm{S}(\mathrm{A})$ & $\mathrm{T}(\mathrm{A})$ & $\mathrm{R}(\mathrm{A})$ & $\mathrm{S}(\mathrm{A})$ & $\mathrm{T}(\mathrm{A})$ \\
\hline 220 & 0 & 0.00 & 0.00 & 0.00 & 0.001 & 0.002 & 0.002 \\
\hline 220 & 40 & 0.18 & 0.17 & 0.20 & 0.179 & 0.182 & 0.183 \\
\hline 220 & $\begin{array}{c}\mathrm{R}=65 \\
\mathrm{~S}=140 \\
\mathrm{~T}=140\end{array}$ & 0.30 & 0.62 & 0.63 & 0.290 & 0.618 & 0.624 \\
\hline
\end{tabular}

Tabel 2. Pengujian sensor ACS712 dengan tegangan 188Vac

\begin{tabular}{|c|c|c|c|c|c|c|c|}
\hline \multirow{2}{*}{$\begin{array}{c}\text { Tegangan } \\
\text { (Vs) }\end{array}$} & \multirow{2}{*}{$\begin{array}{c}\text { Beban } \\
\text { (Watt) }\end{array}$} & \multicolumn{3}{|c|}{ Sensor } & \multicolumn{3}{|c|}{ Ampermeter } \\
\cline { 3 - 8 } & & $\mathrm{R}(\mathrm{A})$ & $\mathrm{S}(\mathrm{A})$ & $\mathrm{T}(\mathrm{A})$ & $\mathrm{R}(\mathrm{A})$ & $\mathrm{S}(\mathrm{A})$ & $\mathrm{T}(\mathrm{A})$ \\
\hline 188 & 40 & 0.17 & 0.17 & 0.18 & 0.166 & 0.167 & 0.168 \\
\hline \multirow{2}{*}{188} & $\mathrm{R}=65$ & & & & & & \\
& $\mathrm{~S}=140$ & 0.28 & 0.56 & 0.59 & 0.268 & 0.571 & 0.403 \\
& $\mathrm{~T}=140$ & & & & & & \\
\hline
\end{tabular}




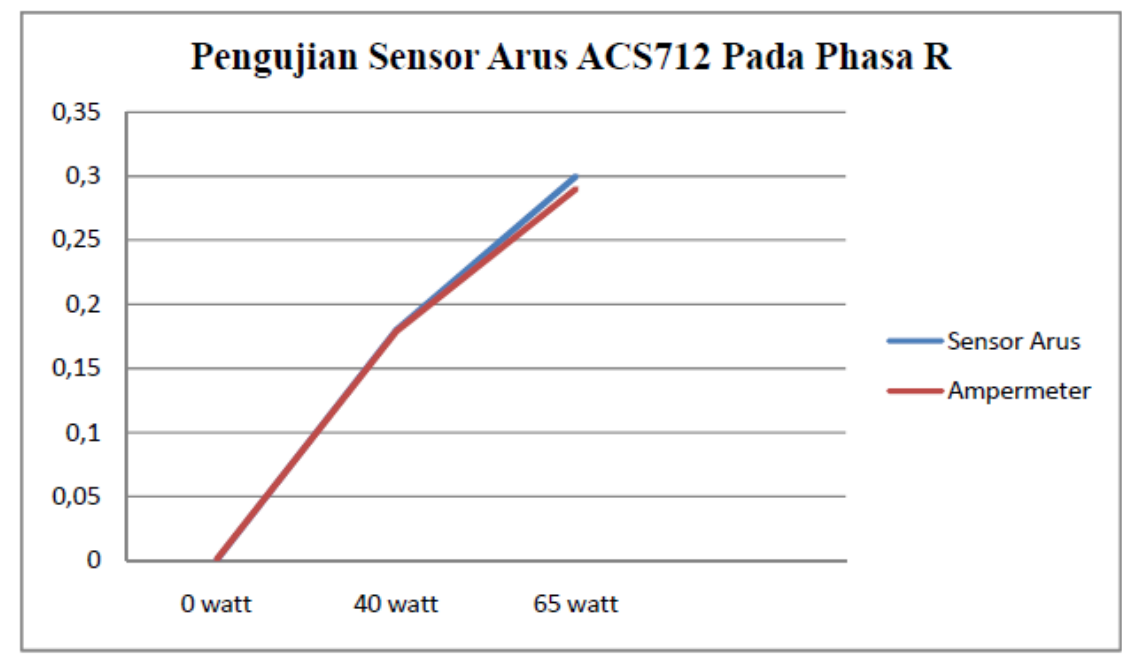

Gambar 5. Pengujian sensosr ACS712 pada phasa R

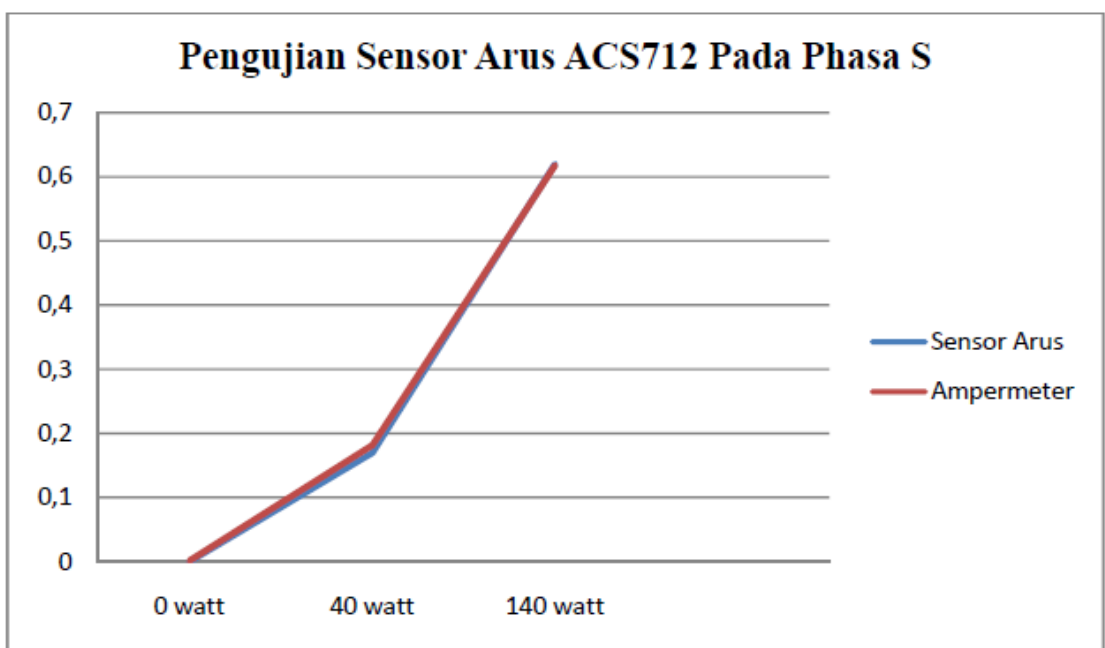

Gambar 6. Pengujian sensosr ACS712 pada phasa S

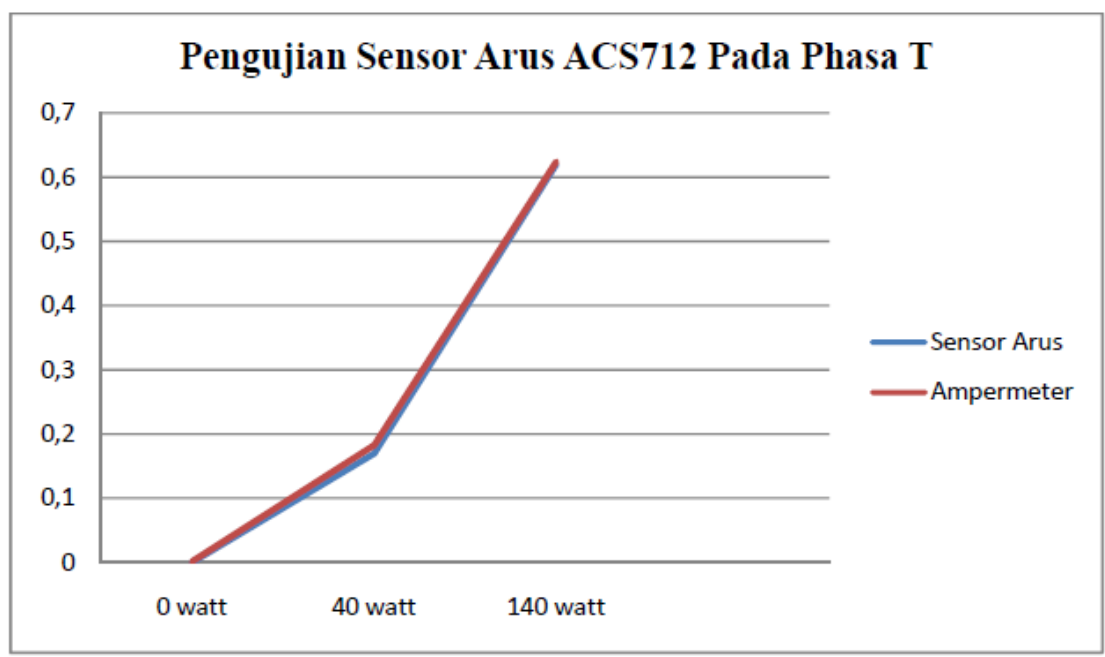

Gambar 7. Pengujian sensosr ACS712 pada phasa T

Dari grafik yang nampak diatas, terlihat jelas pengukuran antara sensor arus ACS712 dengan ampermeter hampir sama. Hanya terdapat beberapa data yang pengukurannya tidak sama. Hal ini disebabkan oleh adanya pengukuran eror-eror pada sensor arus karena 
disebabkan faktor gangguan luar. Namun dari hasil pengujian diatas, kerja dari sensor arus tersebut bisa dikatakan akurat dengan amperemeter.

Pada pengujian kedua dilakukan untuk mengetes sensitifitas dari sensor tegangan ZMPT101B. Sensor tegangan ini dapat mengukur tegangan hingga 250 Volt AC. Pemasangan sensor ini dilakukan secara paralel. Agar pembacaan sensor bisa lebih presisi atau sesuai dengan voltmeter, maka potensio pada modul sensor tegangan tersebut dapat diatur. Tujuan dari pengujian ini sama dengan pengujian pada sensor arus sebelumnya. Selain untuk menguji sensitifitas pembacaan tegangan oleh sensor, hasil pengukuran sensor tersebut juga akan dibandingan dengan hasil pengukuran manual menggunakan voltmeter. Tabel 3 berikut merupakan hasil pengujian sensor tegangan ZMPT101B tersebut.

Tabel 3. Hasil pengujian tegangan dengan sensor ZMPT101B

\begin{tabular}{|c|c|c|c|c|c|c|}
\hline \multirow{2}{*}{$\begin{array}{c}\text { Tegangan } \\
\text { (Vs) }\end{array}$} & \multicolumn{2}{|c|}{ Pengukuran Sensor ZMPT101B } & \multicolumn{3}{c|}{ Pengukuran dengan Voltmeter } \\
\cline { 2 - 7 } & $\mathrm{R}$ (Volt) & $\mathrm{S}$ (Volt) & $\mathrm{T}$ (Volt) & $\mathrm{R}$ (Volt) & $\mathrm{S}$ (Volt) & $\mathrm{T}$ (Volt) \\
\hline 0 & 0.73 & 0.85 & 0.79 & 0.0005 & 0.0003 & 0.0004 \\
\hline 22 & 24.68 & 24.09 & 24.52 & 23.72 & 23.65 & 23.58 \\
\hline 95 & 107.57 & 105.71 & 106.91 & 103.7 & 103.4 & 103.2 \\
\hline 188 & 212.57 & 209.48 & 211.89 & 204.4 & 204.0 & 203.8 \\
\hline 220 & 238.34 & 238.49 & 238.57 & 238.4 & 238.4 & 238.9 \\
\hline
\end{tabular}

Berikut merupakan grafik perbandingan pengukuran antara sensor tegangan ZMPT101B dengan voltmeter. Pada pengukuran ini tegangan sumber dibuat variabel.

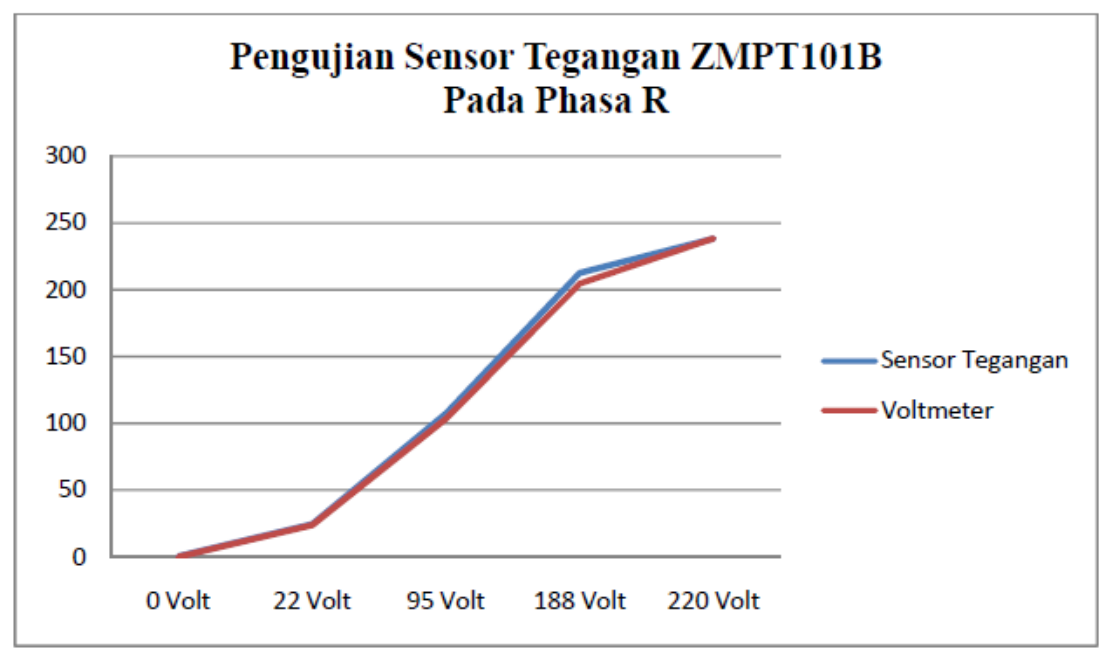

Gambar 7. Pengujian sensor ZMPT pada phasa R 


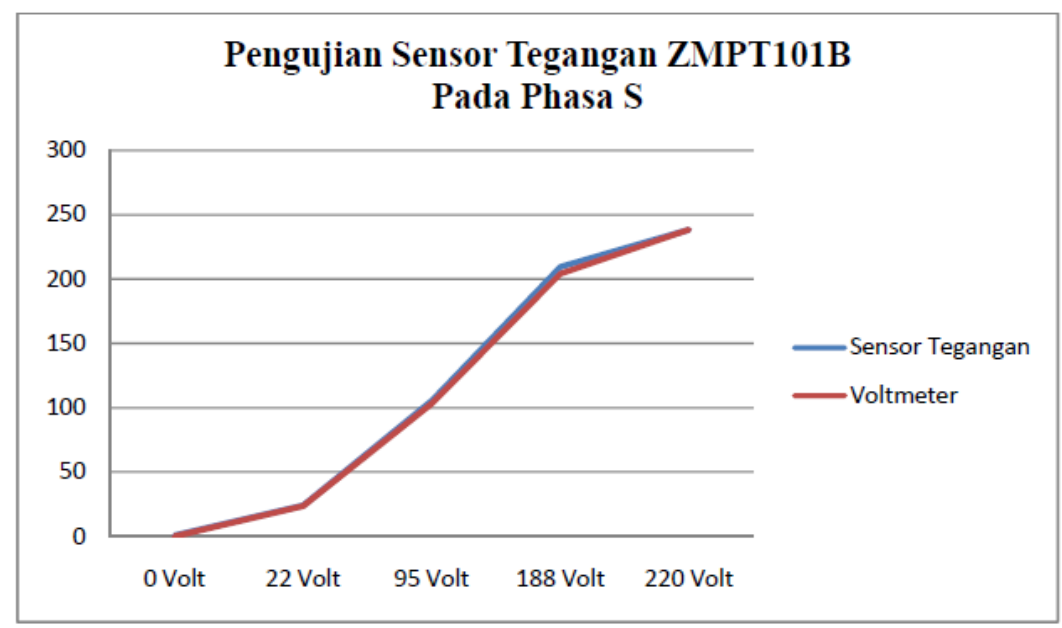

Gambar 8. Pengujian sensor ZMPT pada phasa S

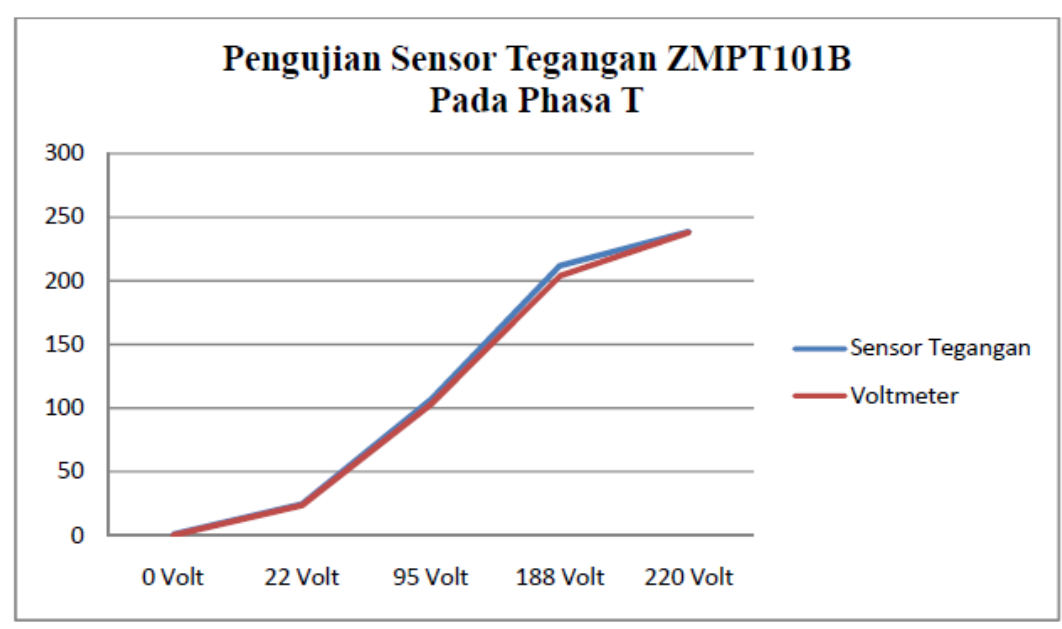

Gambar 9. Pengujian sensor ZMPT pada phasa T

Dari grafik yang ada diatas, terlihat jelas pengukuran antara sensor tegangan dengan voltmeter hampir sama. Hanya terdapat beberapa data yang pengukurannya tidak sama. Hal ini disebabkan oleh adanya pengukuran eror-eror pada sensor tegangan karena disebabkan faktor gangguan luar. Namun dari hasil pengujian diatas, kerja dari sensor tegangan tersebut bisa dikatakan akurat dengan voltmeter.

\section{ANALISA}

Pengujian keseluruhan pada rancang bangun sistem proteksi generator dari arus beban lebih dan drop tegangan ini dilakukan untuk memastikan setiap bagian dari alat tersebut sudah dapat berfungsi dan digunakan sebagaimana mestinya. Pada pengujian ini dilakukan pengambilan data dengan menggunakan rancang bangun alat ini. Data yang diperoleh dari pengujian kemudian akan dibandingkan dengan data yang diperoleh dari perhitungan. Dikarenakan alat ini digunakan untuk memproteksi generator, maka untuk penyetingan batas arus dan tegangannya disesuaikan dengan data dari name plat generator tersebut. Data perhitungan yang dilakukan secara teoritis tersebut meliputi bagaimana melakukan perhitungan untuk menentukan nilai arus (Isetting) dan tegangan (Vsetting). Berikut merupakan perhitungan menentukan nilai Vsetting, batas drop tegangan yang diizinkan pada percobaan ini adalah sebesar $10 \%$, maka untuk perhitungannya sebagai berikut :

1. Untuk Vsetting $10 \%$

$\mathrm{Vn}=220 \times 10 \%$ 


$$
\mathrm{Vn}=22 \text { Volt }
$$

Vsetting $=220-\mathrm{Vn}$

Vsetting $=220-22$

Vsetting $=198$ Volt

Jadi setting tegangan yang digunakan adalah sebesar 198 Volt

Setelah mendapatkan hasil perhitungan untuk menentukan nilai batas tegangan yang dibutuhkan. Maka nilai tersebut akan diinputkan ke rancang bangun alat proteksi generator tersebut. Perhitungan ini didasarkan dan mengacu kepada sistem proteksi Under Voltage Relay, modul UVR yang dipakai ketika melakukan praktikum proteksi. Untuk setting pada drop tegangan, batas drop tegangan yang diizinkan sebesar $10 \%$ dari tegangan sumber sebesar 220 volt. Besar nilai tersebut adalah sebesar 198 volt. Apabila tegangan yang terukur masih berada dibawah $10 \%$ seperti pada beban 600 watt dan 900 watt, maka suplai ke beban masih terhubung. Pada kasus beban 1200 watt drop tegangan terukur melebihi $10 \%$. Hal ini menyebabkan suplai daya dri sumber ke beban diputus oleh PMT.

Berikut merupakan perhitungan berapa persen drop tegangan pada setiap beban :

1. Beban 600 watt

\begin{tabular}{|l|l|l|}
\hline \multicolumn{1}{|c|}{$\mathrm{R}$} & \multicolumn{1}{|c|}{$\mathrm{S}$} & \multicolumn{1}{c|}{$\mathrm{T}$} \\
\hline $\mathrm{V}_{\text {drop }}=\frac{219}{220} \times 100 \%$ & $\mathrm{~V}_{\text {drop }}=\frac{219}{220} \times 100 \%$ & $\mathrm{~V}_{\text {drop }}=\frac{218}{220} \times 100 \%$ \\
$\mathrm{~V}_{\text {drop }}=99,54 \%$ & $\mathrm{~V}_{\text {drop }}=99,54 \%$ & $\mathrm{~V}_{\text {drop }}=99,09 \%$ \\
$\mathrm{~V}_{\text {drop }}=100 \%-99,54 \%$ & $\mathrm{~V}_{\text {drop }}=100 \%-99,54 \%$ & $\mathrm{~V}_{\text {drop }}=100 \%-99,09 \%$ \\
$\mathrm{~V}_{\text {drop }}=0,46 \%$ & $\mathrm{~V}_{\text {drop }}=0,46 \%$ & $\mathrm{~V}_{\text {drop }}=0,91 \%$ \\
\hline
\end{tabular}

Untuk beban 600 watt ini, drop tegangan yang terjadi masih dibawah $10 \%$ yaitu sebesar 0,46 $\%$ di fasa R, 0,46 di fasa $\mathrm{S}$, dan 0,91 di fasa T. Sehingga suplai tenaga masih terhubung ke beban dan masih dalam kategori aman.

2. Beban 1200 watt

\begin{tabular}{|c|c|c|}
\hline $\mathrm{R}$ & $\mathrm{S}$ & $\mathrm{T}$ \\
\hline $\begin{array}{l}\mathrm{V}_{\text {drop }}=\frac{181}{220} \times 100 \% \\
\mathrm{~V}_{\text {drop }}=82,27 \% \\
\mathrm{~V}_{\text {drop }}=100 \%-82,27 \% \\
\mathrm{~V}_{\text {drop }}=17,73 \%\end{array}$ & $\begin{array}{l}V_{\text {drop }}=\frac{180}{220} \times 100 \% \\
V_{\text {drop }}=81,81 \% \\
V_{\text {drop }}=100 \%-81,81 \% \\
V_{\text {drop }}=18,19 \%\end{array}$ & $\begin{aligned} V_{\text {drop }} & =\frac{179}{220} \times 100 \% \\
V_{\text {drop }} & =81,36 \% \\
V_{\text {drop }} & =100 \%-81,36 \% \\
V_{\text {drop }} & =18,64 \%\end{aligned}$ \\
\hline
\end{tabular}

Untuk beban 1200 watt ini, drop tegangan yang terjadi sudah diatas $10 \%$ yaitu sebesar 17,73 $\%$ di fasa $\mathrm{R} ; 18,19 \%$ di fasa $\mathrm{S}$ dan $18,64 \%$ di fasa T. Sehingga suplai tenaga ke beban sudah diputus oleh PMT dalam waktu 1 detik dikarenakan oleh drop tegangan.

Untuk pengaturan arusnya, ditentukan dulu berapa besar kapasitas beban yang dapat diangkatkan oleh generator. Pada pengujian kali ini, penulis menggunakan generator dengan kapasitas daya yang bisa disuplai sebesar 1000 watt. Untuk keamanan penulis menggunakan beban 900 watt sebagai batas beban maksimal yang dapat digunakan. Apabila beban yang digunakan melebihi maka suplai dari generator ke beban akan diputuskan oleh PMT. Setelah besar daya beban yang dipakai ditentukan,maka untuk perhitungan arus (Isetting) yang digunakan sebagai batas arus yang boleh mengalir pada beban, dilakukan perhitungan secara teoritis seperti berikut :

$$
\begin{aligned}
& \mathrm{P}=\mathrm{V} . \mathrm{I} \\
& \mathrm{I}=\mathrm{P} / \mathrm{V} \\
& \mathrm{I}=300 / 220
\end{aligned}
$$




$$
\begin{array}{ll}
\text { I }=1,3 \mathrm{~A} & \\
\text { Isetting } & =110 \% \mathrm{x} \mathrm{In} \\
& =1,1 \times 1,3 \\
& =1,43 \mathrm{~A}
\end{array}
$$

Jadi besar setting arus yang digunakan adalah sebesar 1,43 A.

Semua data tentang penyetingan arus dan tegangan yang didapat dari perhitungan ini akan digunakan untuk melakukan pengukuran. Nilai Isetting dan V setting akan dimasukkan sebagai batas nilai arus dan tegangan.

Setelah semua data untuk diinputkan ke alat, maka dilakukan pengujian dan hasil dari pengujian tersebut maka didapatkan hasil pengujian seperti yang terdapat pada tabel.

Kemudian untuk pengujian arus, pada beban 600 watt arus yang terukur masih lebih kecil dibandingkan dengan Isetting, sehingga suplai dari generator masih terhubung ke beban. Untuk beban 900 watt, arus yang terukur juga masih lebih kecil dibandingkan dengan Isetting sehingga suplai dari sumber ke beban masih terhubung. Namun pada beban 1200 watt, arus yang terukur lebih besar dibandingkan dengan Isetting. Ini menyebabkan PMT trip sehingga suplai tenaga ke beban terputus

1. Beban 600 watt

\begin{tabular}{|l|l|l|}
\hline \multicolumn{1}{|c|}{$\mathrm{R}$} & \multicolumn{1}{c|}{$\mathrm{S}$} & \multicolumn{1}{c|}{$\mathrm{T}$} \\
\hline$\Delta \mathrm{I}=0,86-1,43$ & $\Delta \mathrm{I}=0,85-1,43$ & $\Delta \mathrm{I}=0,83-1,43$ \\
$\Delta \mathrm{I}=-0,57 \mathrm{~A}$ & $\Delta \mathrm{I}=-0,58 \mathrm{~A}$ & $\Delta \mathrm{I}=-0,6 \mathrm{~A}$ \\
\hline
\end{tabular}

Untuk beban 600 watt, arus yang terukur pada setiap fasanya masih berada dibawah Isettingnya. Pada fasa $\mathrm{R}$ terukur arus lebih kecil $0,57 \mathrm{~A}$, pada fasa $\mathrm{S}$ arus terukur lebih kecil 0,58 A dari Isetting dan pada fasa $\mathrm{T}$ arus terukur lebih kecil 0,6 A dari Isettingnya.

2. Beban 1200 watt

\begin{tabular}{|l|l|l|}
\hline \multicolumn{1}{|c|}{$\mathrm{R}$} & \multicolumn{1}{|c|}{$\mathrm{S}$} & \multicolumn{1}{c|}{$\mathrm{T}$} \\
\hline$\Delta \mathrm{I}=1,45-1,43$ & $\Delta \mathrm{I}=1,51-1,43$ & $\Delta \mathrm{I}=1,60-1,43$ \\
$\Delta \mathrm{I}=0,02 \mathrm{~A}$ & $\Delta \mathrm{I}=0,08 \mathrm{~A}$ & $\Delta \mathrm{I}=0,17 \mathrm{~A}$ \\
\hline
\end{tabular}

Untuk beban 1200 watt, arus yang terukur pada setiap fasanya sudah berada diatas dari Isettingnya. Pada fasa $\mathrm{R}$ terukur arus lebih besar 0,02 A dari Isettingnya, pada fasa $\mathrm{S}$ arus terukur lebih besar 0,08 A dari Isetting dan pada fasa $\mathrm{T}$ arus terukur lebih besar 0,17 A dari Isettingnya. Ini menyebabkan PMT memutus suplai tenaga ke beban dikarenakan terjadi arus beban lebih.

\section{KESIMPULAN}

Berdasarkan hasil pengujian alat dan pembahasan yang telah dilakukan, maka dapat disimpulkan beberapa hal berikut :

1. Sensor arus ACS712 dan sensor tegangan ZMPT101B yang digunakan untuk mengukur arus beban lebih dan drop tegangan dapat berfungsi dengan baik, walaupun ada eror eror yang terjadi yang disebabkan oleh sensor itu sendiri maupun faktor luar.

2. Semakin besar beban yang digunakan maka akan semakin besar pula arus dan tegangan akan semakin kecil.

3. Rancang bangun sistem proteksi generator ini dapat berfungsi dengan baik.

\section{REFERENSI}

[1] Badan Standarisasi Nasional. 2000. Persyaratan Umum Instalasi Listrik 2000 (PUIL2000). Jakarta

[2] Kadir, Abdul. 2014. Buku Pintar Pemograman Arduino. Yogyakarta. Mediacom 
[3] Teori Generator Sinkron (2012). Diakses terakhir Januari 30, 2015. Medan : Universitas Sumatera Utara

[4] Zuhal. 1995. Dasar Teknik Tenaga Listrik dan Elektronika Daya. Jakarta : PT Gramedia Pustaka Utama.

[5] Wasito.S. 2001. Vademekum Elektronika. Edisi 2. Jakarta : PT Gramedia Pustaka Utama.

[6] Refki, Diana, Permata. 2013. Pendeteksi dan Pengaman Kebocoran Gas LPGBerbasiskan Mikrokontroller AVR Atmega16. Skripsi. Padang. Universitas Negeri Padang.

[7] Panjaitan,R. 2000. Mesin Listrik Arus Bolak-Balik. Bandung : Tarsito. 